\title{
COMPARISON STUDY OF VERTICAL CYLINDER TANK DIAMETER MEASUREMENT BETWEEN STRAPPING AND OPTICAL METHOD
}

\author{
Vera Firmansyah ${ }^{1, *}$, Purwanto Nugroho ${ }^{2}$, Herfin Yienda Prihensa ${ }^{3}$, \\ Azis Muslim ${ }^{1}$
}

${ }^{1}$ Akademi Metrologi dan Instrumentasi. Jl. Daeng Muhammad Ardiwinata KM. 3,4, Cihanjuang, Kec. Parongpong, Kabupaten Bandung Barat, Jawa Barat 40559, Indonesia 2Direktorat Metrologi. Jl. Pasteur No. 27 Bandung, Jawa Barat, Indonesia 3Pusat Pengembangan Sumber Daya Kemetrologian. Jl. Daeng Muhammad Ardiwinata KM. 3,4, Cihanjuang, Kec. Parongpong, Kabupaten Bandung Barat, Jawa Barat 40559, Indonesia

*Corresponding Author Email: vera.firmansyah@kemendag.go.id

Received: 5 August 2020

Revised: 22 October 2020 Accepted: 27 October 2020

Online: 2 December 2020

Published: 31 December 2020

SPEKTRA: Jurnal Fisika dan Aplikasinya p-ISSN: 2541-3384

e-ISSN: 2541-3392

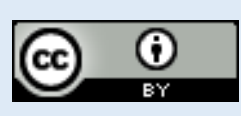

\begin{abstract}
Vertical Cylinder Tank is used as a storage area or as a measuring tool. Liquids are used in the form of Fuel oil, Liquid Natural Gas, vegetable liquids, and other chemical liquids. The tank calibration results are in the form of a volume per height table that is used as a reference by Automatic Tank Gauging. There are two tank calibration methods, namely: the strapping method and the optical method. The process of measuring the inside or outside diameter of the tank becomes very important in the tank calibration process-the measurement of tank diameter by the strapping method using steel meters manually. At the same time, the optical method uses theodolite or total station. For tank diameters $\leq 5 \mathrm{~m}$, the strapping method has smaller diameter measurement results with a difference of $0.7 \%$ compared to the optical method. In further research, a prototype can be developed that can accelerate the calibration process using the strapping method (for example, a vertical track measuring robot) or a low-cost prototype theodolite.
\end{abstract}

Keywords: vertical cylinder tank, calibration, strapping method, optical method 


\section{INTRODUCTION}

The vertical cylinder tank is a cylindrical measuring tool. It is generally used as a storage or as a measurement tool at the time of delivery-liquids used in the form of fuel oil, LNG, vegetable liquids, and other chemical liquids. The final results of the calibration of vertical cylindrical are the table volume per altitude, where the table is used as a reference for other tank volume monitoring devices (an example is automatic tank gauging or automatic level gauging)[1]. Thus, the accuracy of the test results of a vertical cylinder becomes very important.

Testing vertical cylindrical tanks are generally divided into two parts, namely: volumetric methods and geometric methods. The volumetric method is used for vertical cylindrical tank volumes of less than $50 \mathrm{kl}$, with the standard being a standard measuring vessel and a flow meter [2] that is calibrated by the volumetric method [3]. At the same time, the geometric method is divided into two, namely: the strapping method and optical method. The strapping method uses steel meter standards [4-6] and optical methods that use theodolite or total station standards [7-10] that are located in outside of the tank. For the inside of the tank, a comparison of the two methods above has been produced, but it is not stated which method is better [11]. Strapping method testing requires more time and more personnel compared to the optical method. Geometric methods are used for capacities greater than $50 \mathrm{kl}$. Some even test 300,000 $\mathrm{kl}[12]$.

The latest developments on vertical cylindrical tank testing methods are using 3D scanning [13], which provides many advantages: saving time on testing, not using water fluid to calculate swamps, can be used at low temperatures, and only requires one person. The results of the vertical cylindrical tank testing method with $3 \mathrm{D}$ scanning are around $\pm 0.2 \%$ (for the middle to the top) [14] and enlarged with a limit of $\pm 0.5 \%$ (for the middle to the bottom). So, this 3D scanning method cannot be used as a reference as a vertical cylindrical tank testing technique because it is still beyond the provisions limit of $0.2 \%[2,14]$.

The results of this study provide an option to make a prototype that can shorten the calibration time using the strapping method-for example, making a wall-climbing robot [15-17] equipped with a distance gauge. Alternatively, make a prototype that has a working system such as theodolite at a low cost.

\section{METHOD OF GEOMETRIC}

The method of geometric testing measures tank cylinder vertical, namely: the measurement of the circumference, measuring $\Delta \mathrm{R}$ (the difference between the radius of the ring-n to the radius ring-1), height measurement, measurement of plate thickness ring, the measurement object correction, and measuring the contents of the swamp [2,4]. The difference between a strapping method and an optical method is the circumference measurement process and measurement $\Delta \mathrm{R}$. Before testing, the tank cylinder vertical divided into several rings (FIGURE 1) and several segments (FIGURE 2a). 


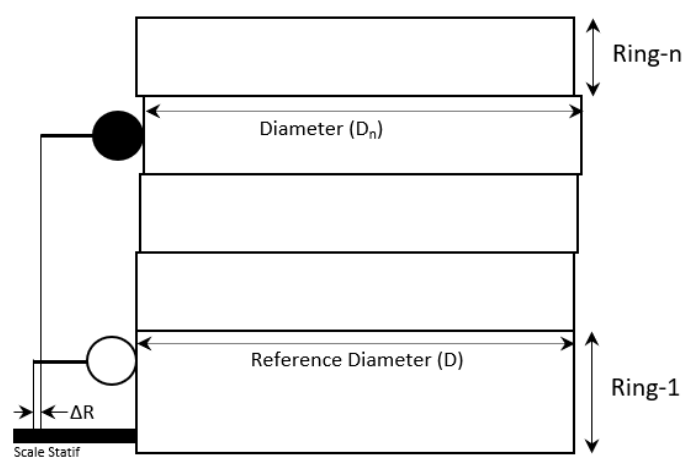

(a)

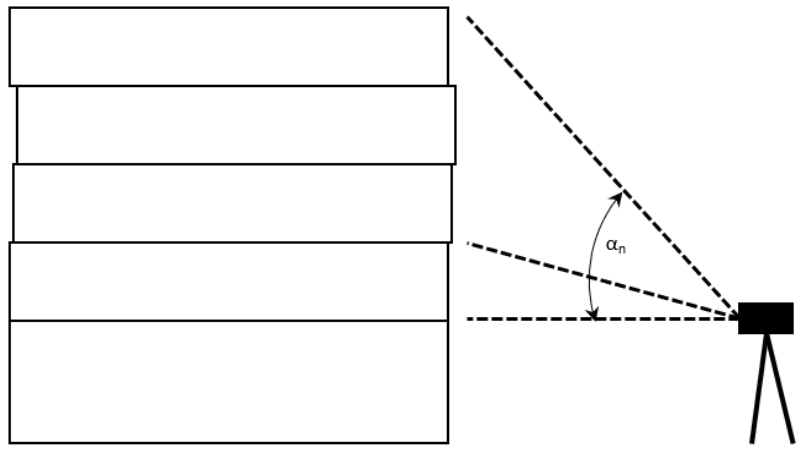

(b)

FIGURE 1. Illustration Reference Diameter and Distribution Ring vertical cylindrical tanks (a) Diameter Difference Measurement Process Each Ring Against Method Reference Diameter Strapping, (b) Measurement Process Reference Diameter and Vertical Angle Measurement Method Each Rings Optics.

The ring is part of a cylindrical tank bottom edge, and the top edge is limited by weld or rivet connection with the circular, in the method of measuring the diameter of a reference strapping using steel ruler corrected by a correction value on the certificate and correction of material elongation steel ruler at the time of measurement. Reference diameter measurement results must also be corrected by an expansion of the tank wall itself, for strapping method and optical methods. The strapping method measures the diameter of the ring-n that is by measuring the difference in the radius of the ring-n to the radius reference (ring-1) for every segment.

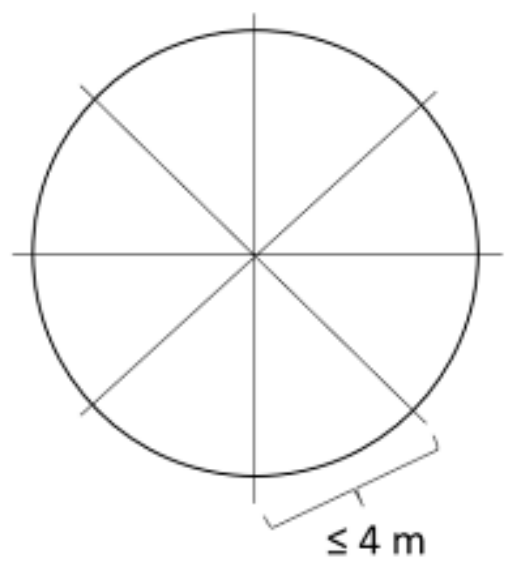

(a)

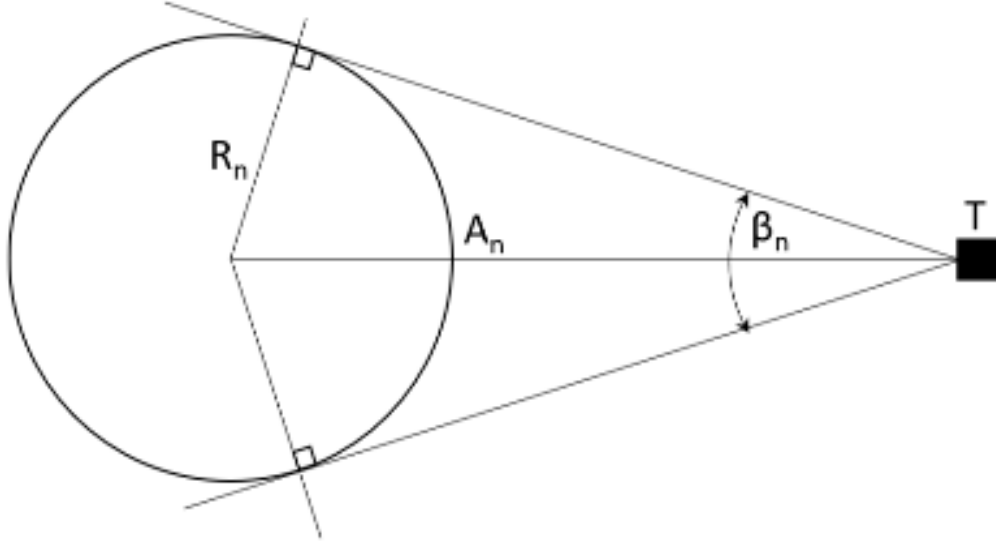

(b)

FIGURE 2. Illustration vertical cylinder tank Looks Up (a) The distribution segment, (b) the horizontal angle measurement Each ring and each segment Optical Methods.

The entire segment on the following strapping provisions: minimum 12 segments, a segment closest up to $4 \mathrm{~m}$, and have an even number of segments [2]. In optical methods, as well as a segment called a theodolite position. The position is set based around a vertical cylindrical tank that will be tested, as an example to around $\leq 50 \mathrm{~m}$ at least five positions. To measure the radius of each ring can use the EQUATION (1). 


$$
R_{n}=\frac{T A_{n} \cos \left(\alpha_{n}\right) \sin \left(\frac{\beta_{n}}{2}\right)}{1-\sin \left(\frac{\beta_{n}}{2}\right)}
$$

Where: $\mathrm{n}$ is the number of rings, $\mathrm{R}$ is the radius, TA is the distance between the theodolite with the midpoint tank cylinder vertical and $\beta$ is the angle formed between the two sides tank vertical cylinder. In reference radius $\cos \alpha$ equal to 1 . If the circumference of the ring of steel then reference $\left(\mathrm{K}_{\mathrm{ref}}\right)$ using the meter to calculate the radius of the ring-n can use the EQUATION (2) [8].

$$
R_{n}=\frac{K_{r e f} \sin \left(\frac{\beta_{n}}{2}\right)}{2 \pi \sin \left(\frac{\beta_{1}}{2}\right)}
$$

Where: $\beta_{1}$ is the angle formed on the reference ring, and $\beta_{\mathrm{n}}$ is the angle formed at the ring-n.

\section{RESULT AND DISCUSSION}

The data used in this paper is the tank's vertical cylinder in the PPSDK Ministry of Trade. A vertical cylinder tank is used for the needs of the learning lab for Metrology Training and to support one practicum class at the Academy of Metrology and Instrumentation Ministry of the Trade. Tank cylinder vertical in PPSDK has a capacity of 78,494 liters, the tank wall expansion coefficient material $1.12 \mathrm{e}-5 /{ }^{\circ} \mathrm{C}$, and roving reference $\left(\mathrm{K}_{\mathrm{ref}}\right)$ amounting to $12,720 \mathrm{~mm}$ at a temperature of $28^{\circ} \mathrm{C}$.

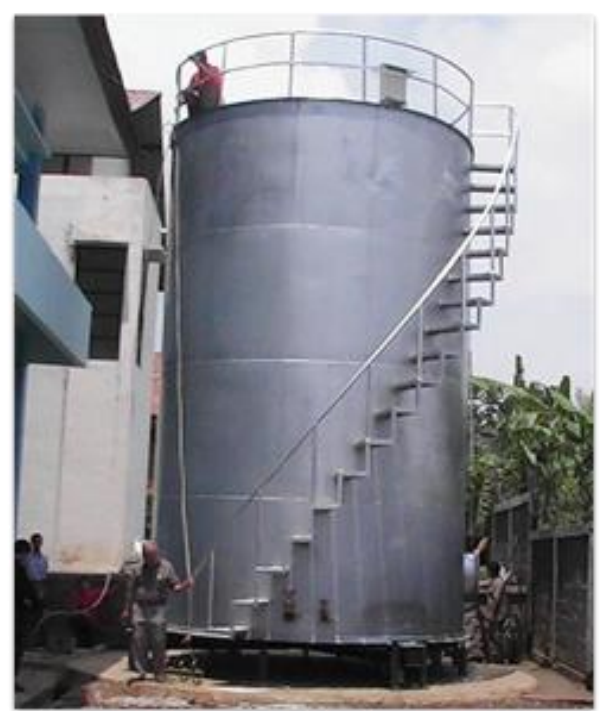

(a)

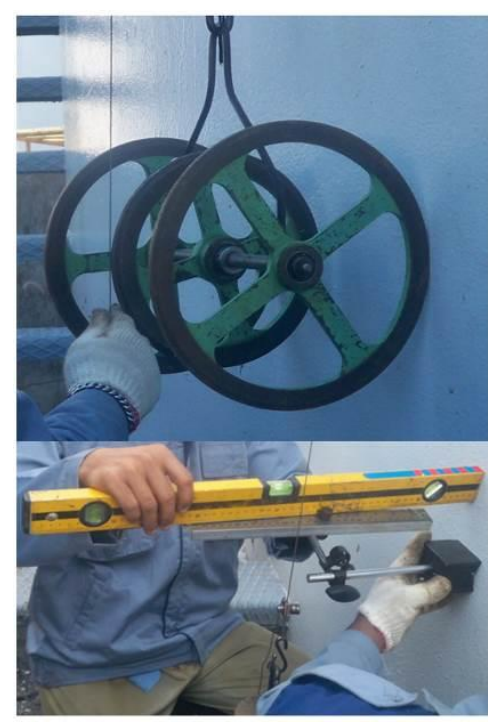

(b)

FIGURE 3. (a) Tanks Vertical Cylinder in PPSDK (b). Strapping Tools and Process Measurement difference Radius. 
The vertical cylinder tank has four rings, for the strapping method is divided into twelve pie and for the optical method is divided into four positions adapted to the conditions in FIGURE 3.a. Data differences in radii for each segment can be seen in TABLE 1.

TABLE 1. Difference Radius Ring every Segment Against Method Reference Strapping.

\begin{tabular}{|c|c|c|c|c|c|c|c|c|c|c|c|c|}
\hline \multirow{2}{*}{$\begin{array}{l}\text { Segmen } \\
\text { t- }\end{array}$} & \multicolumn{3}{|c|}{ Ring-1 (mm) } & \multicolumn{3}{|c|}{ Ring-2 (mm) } & \multicolumn{3}{|c|}{ Ring-3 (mm) } & \multicolumn{3}{|c|}{ Ring-4 (mm) } \\
\hline & B & $\mathbf{T}$ & $\mathbf{A}$ & B & $\mathbf{T}$ & $\mathbf{A}$ & B & $\mathbf{T}$ & $\mathbf{A}$ & B & $\mathbf{T}$ & $\mathbf{A}$ \\
\hline 1 & 271 & 274 & 273 & 274 & 271 & 274 & 276 & 279 & 280 & 279 & 284 & 285 \\
\hline 2 & 271 & 265 & 256 & 250 & 271 & 265 & 252 & 255 & 257 & 256 & 258 & 264 \\
\hline 3 & 268 & 270 & 271 & 275 & 268 & 270 & 279 & 279 & 275 & 274 & 262 & 261 \\
\hline 4 & 270 & 272 & 273 & 266 & 270 & 272 & 256 & 260 & 250 & 254 & 255 & 260 \\
\hline 5 & 270 & 273 & 266 & 257 & 270 & 273 & 240 & 240 & 230 & 240 & 235 & 245 \\
\hline 6 & 269 & 273 & 272 & 275 & 269 & 273 & 279 & 283 & 280 & 285 & 291 & 292 \\
\hline 7 & 265 & 270 & 271 & 276 & 265 & 270 & 280 & 291 & 288 & 298 & 299 & 305 \\
\hline 8 & 271 & 278 & 279 & 256 & 271 & 278 & 256 & 264 & 262 & 260 & 257 & 258 \\
\hline 9 & 271 & 264 & 261 & 260 & 271 & 264 & 248 & 246 & 237 & 232 & 230 & 229 \\
\hline 10 & 265 & 266 & 267 & 255 & 265 & 266 & 250 & 243 & 230 & 240 & 240 & 242 \\
\hline 11 & 255 & 259 & 257 & 245 & 255 & 259 & 240 & 235 & 235 & 230 & 230 & 235 \\
\hline 12 & 277 & 282 & 284 & 290 & 277 & 282 & 292 & 297 & 301 & 304 & 295 & 297 \\
\hline$\sum \Delta \mathbf{R}$ & 3223 & 3246 & 3230 & 3179 & 3223 & 3246 & 3148 & 3172 & 3125 & $\begin{array}{l}315 \\
2 \\
\end{array}$ & $\begin{array}{l}313 \\
6 \\
\end{array}$ & 3173 \\
\hline $\begin{array}{l}\sum \Delta \mathbf{R}_{\mathbf{i}}- \\
\sum \Delta \mathbf{R}_{\mathrm{ref}}\end{array}$ & -23 & 0 & 16 & -67 & -23 & 0 & -98 & -74 & -121 & -94 & -110 & -73 \\
\hline $\begin{array}{l}\text { Average } \\
\text { (/ring) }\end{array}$ & 3.00 & & & -14.00 & & & -81.67 & & & -76.3 & & \\
\hline
\end{tabular}

Each ring is made of three measurements, namely: the position B (bottom), the position T (middle) and the position of A (top). The position of the ring T-1 as a reference calculation of the difference in the radius to all positions on each ring. In TABLE 2 is the result of the acquisition of the data in the form theodolite angle and distance to the mean cross-sectional tank vertical cylinder on one of the notch (segment-1) and a ring-1.

TABEL 2. Theodolite Data Acquisition on a Segment-1 and Ring-1 Optical Methods.

\begin{tabular}{|c|c|c|c|c|c|c|c|c|c|}
\hline \multirow{2}{*}{ Position } & \multicolumn{3}{|c|}{ Right Side } & \multicolumn{3}{|c|}{ Left Side } & \multirow{2}{*}{$\begin{array}{l}\text { Difference } \\
\left(^{\circ}\right)\end{array}$} & \multirow{2}{*}{ TA $(\mathbf{m m})$} & \multirow{2}{*}{ Radius (mm) } \\
\hline & o & ' & ", & o & ' & ، & & & \\
\hline B & 177 & 47 & 0 & 158 & 1 & 27 & 19.76 & 4613.92 & 2026.84 \\
\hline $\mathrm{T}$ & 177 & 47 & 2 & 158 & 1 & 30 & 19.76 & 4613.92 & 2026.26 \\
\hline A & 177 & 47 & 0 & 158 & 1 & 33 & 19.76 & 4613.92 & 2023.38 \\
\hline
\end{tabular}




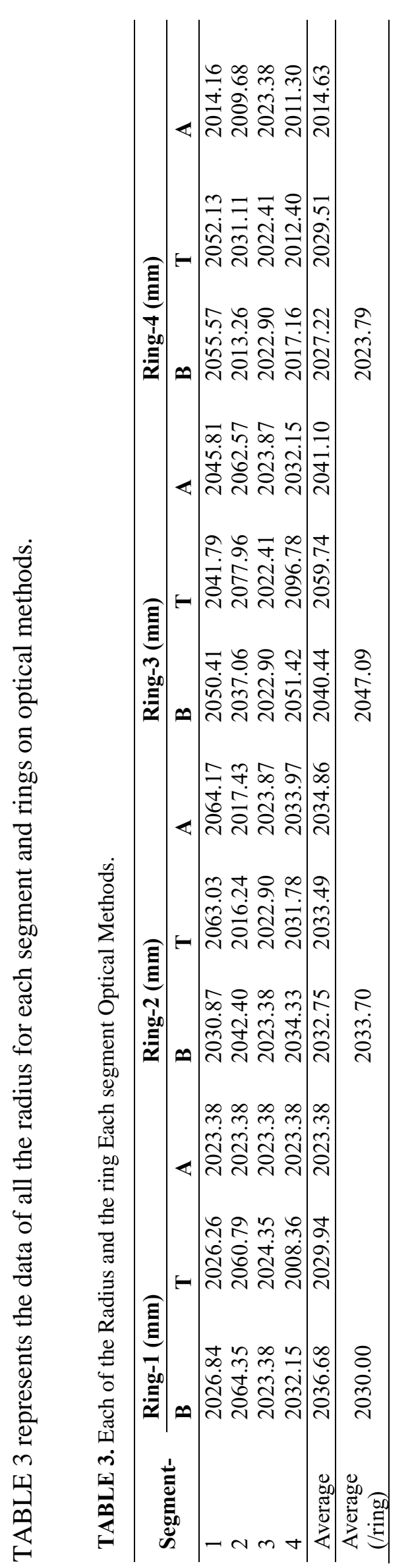

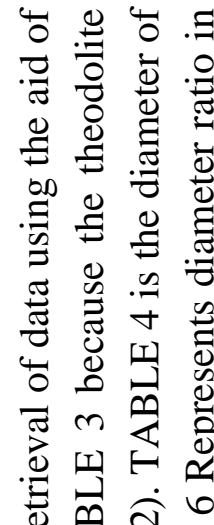

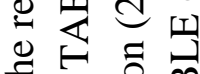

동

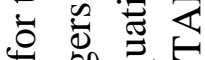

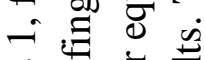

덕

进氞苞

:

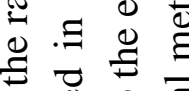

च

ఖ

造育

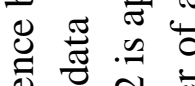

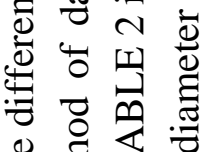

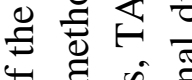

पै

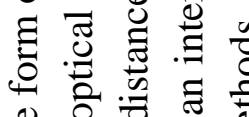

छ 0 : 0 ह

$\Xi \Xi$ 公

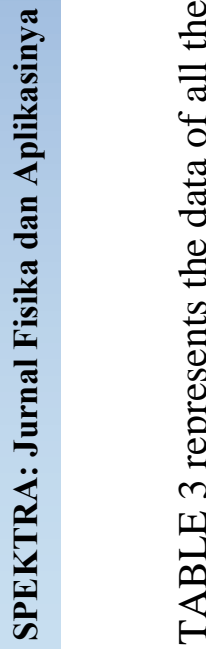

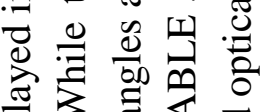

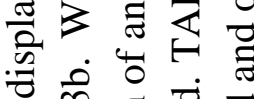

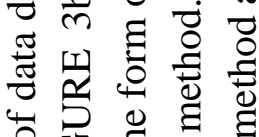

苍记

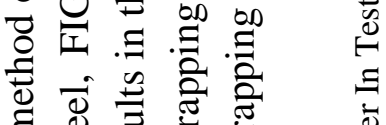

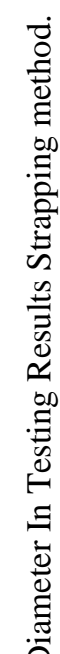

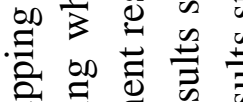

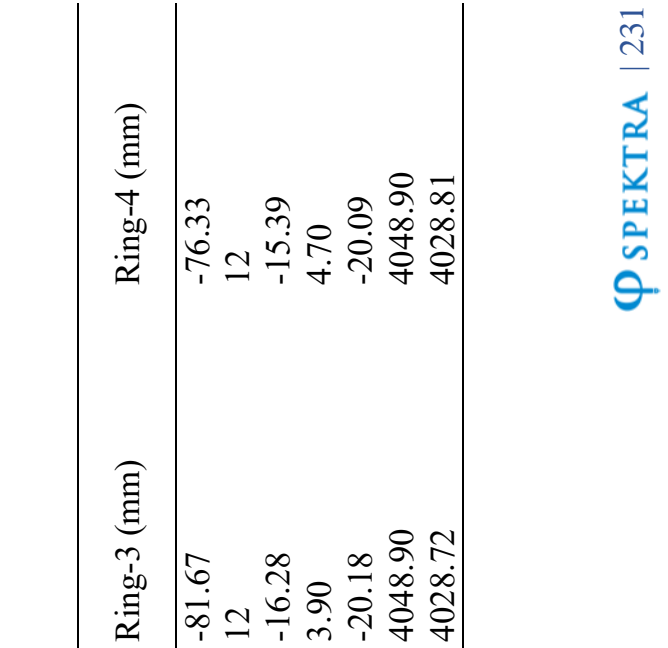

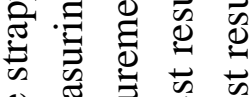

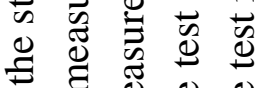

$\stackrel{\Xi}{\Xi} \cong \stackrel{\Xi}{\Xi}$

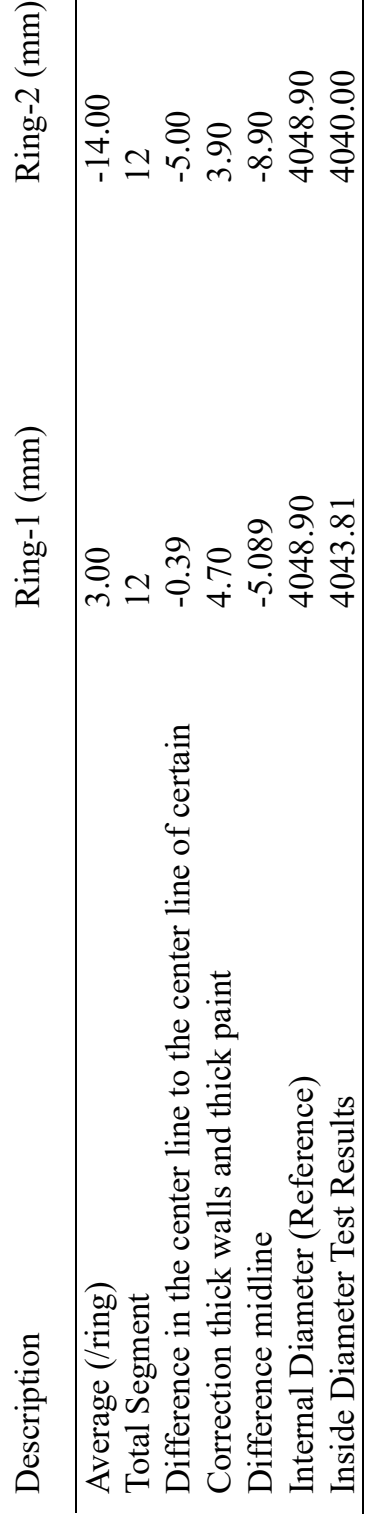


TABLE 5. An Internal Diameter of An Optical Method Test Results.

\begin{tabular}{|c|c|c|c|c|}
\hline Description & Ring-1 (mm) & Ring-2 (mm) & Ring-3 (mm) & Ring-4 (mm) \\
\hline Average (/ring) & 2030.00 & 2033.70 & 2047.09 & 2023.79 \\
\hline Internal Diameter & 4060.00 & 4067.40 & 4094.18 & 4037.58 \\
\hline $\begin{array}{l}\text { Correction thick walls and } \\
\text { thick paint }\end{array}$ & 4.70 & 3.90 & 3.90 & 4.70 \\
\hline $\begin{array}{l}\text { Inside Diameter Test } \\
\text { Results }\end{array}$ & 4055.30 & 4063.50 & 4090.29 & 4042.87 \\
\hline
\end{tabular}

TABLE 6. Represents diameter ratio in the test results strapping method and optical methods.

\begin{tabular}{llll}
\hline Ring- & $\begin{array}{l}\text { Inside Diameter Strapping Methode } \\
(\mathrm{mm})\end{array}$ & $\begin{array}{l}\text { Inside Diameter Optical } \\
\text { Methode }(\mathrm{mm})\end{array}$ & Difference $(\mathrm{mm})$ \\
\hline 1 & 4043.81 & 4055.30 & 11.49 \\
2 & 4040.00 & 4063.50 & 23.50 \\
3 & 4028.72 & 4090.29 & 61.57 \\
4 & 4028.81 & 4042.87 & 14.06 \\
\hline Average & 4035.33 & 4062.99 & 27.65 \\
\hline
\end{tabular}

It can be seen in TABLE 6 that the test results tank vertical cylinder strapping method has a smaller yield than the optical method for each ring. It also indicates that the method of strapping has a smaller yield by a margin of $0.7 \%$ compared with optical methods. Although the method of the strapping result is smaller than the optical method, but has the disadvantage of testing time longer and requires more personnel than by optical methods. The optical method has the disadvantage that the measuring instrument used is highly sensitive, so if there is a very small shock could alter the readings. In addition, theodolite has fairly expensive [18] and requires special skills to operate the tool.

\section{CONCLUSION}

In cylinder vertical tank testing using the strapping method and optical method, the overall results of measurements for each ring diameter in the strapping method showed a smaller yield compared with optical methods. The average difference between the overall diameter ring strapping method and optical methods of $27.65 \mathrm{~mm}$ or $0.7 \%$.

\section{REFERENCES}

[1] OIML-R85, "Automatic level gauges for measuring the level of liquid in stationary storage tanks," 2008.

[2] Departemen Perdagangan Republik Indonesia, "Syarat Teknis Tangki Ukur Silinder Tegak," in KEPUTUSAN DIREKTUR JENDERAL PERDAGANGAN DALAM NEGERI NOMOR 25/PDN/KEP/3/2010, Direktur Jenderal Perdagangan Dalam Negeri, Kementerian Perdagangan D. ST-25, 2010.

[3] V. Y. Aibe et al., "Flow meter calibration by volumetric method and by weighing method using an innovative system," J. Phys. Conf. Ser, vol. 648, no. 1, pp. 3-6, 2015, doi: 10.1088/1742-6596/648/1/012016. 
[4] ISO-7507-1, "Petroleum and liquid petroleum products - Calibration of vertical cylindrical tanks - Part 1: Strapping method," 2003.

[5] API-MPMS-2.2A, "Manual of Petroleum Management Standard Chapter 2-Tank Calibration. Measurement and Calibration of Upright Cylindrical Tanks by the Manual Tank Strapping Method," 1995.

[6] V. V. Nosach and B. M. Belyaev, "The calibration of large vertical cylindrical tanks by a geometrical method," Meas. Tech, vol. 45, no. 11, pp. 1153-1157, 2002, doi: 10.1023/A:1022062532494.

[7] ISO-7507-2, "Petroleum and liquid petroleum products - Calibration of vertical cylindrical tanks - Part 2: Optical-reference-line method," 2005.

[8] ISO-7507-3, "Petroleum and liquid petroleum products - Calibration of vertical cylindrical tanks - Part 3: Optical-triangulation method," 2006.

[9] ISO-7507-4, "Petroleum and liquid petroleum products - Calibration of vertical cylindrical tanks - Part 4:Internal electro-optical distance-ranging method," 2010.

[10] ISO-7507-5, "Petroleum and liquid petroleum products - Calibration of vertical cylindrical tanks - Part 5:External electro-optical distance-ranging method," 2000.

[11] O. O. Agboola et al., "Comparative Analysis of Manual Strapping Method (MSM) and Electro-Optical Distance Ranging (EODR) Method of Tank Calibration," J. Phys. Conf. Ser, vol. 1378, no. 2, pp. 1-10, 2019.

[12] V. V Nosach and B. M. Belyaev, "Salient Features of Procedures For Geometric Calibration Of Large Vertical Cylindrical Tanks," Meas. Tech, vol. 46, no. 1, pp. 35-37, 2003.

[13] V. Knyva, M. Knyva, and J. Rainys, "New approach to calibration of vertical fuel tanks," Elektron. ir Elektrotechnika, vol. 19, no. 8, pp. 37-40, 2013.

[14] OIML-R71, "Fixed storage tanks. General requirements," in OIML Recomendation, France: OIML, pp. 1-32, 2008.

[15] M. Ahmed, M. Eich, and F. Bernhard, "Design and Control of MIRA: A Lightweight Climbing Robot for Ship Inspection," Int. Lett. Chem. Phys. Astron, vol. 55, pp. 128135, 2018.

[16] K. P. Panchal, "Design \& Develop the Prototype of Wall Climbing Robot," Int. J. Adv. Eng. Res. Dev, vol. 1, no. 05, pp. 1-6, 2018.

[17] S. Nansai and R. Mohan, "A Survey of Wall Climbing Robots: Recent Advances and Challenges," Robotics, vol. 5, no. 3, p. 14, 2016.

[18] O. O. Agboolab et al., "Modelling of cost estimates for the geometrical calibration of upright oil storage tanks," Int. J. Energy Econ. Policy, vol. 10, no. 1, pp. 464-470, 2020. 